\title{
Medical thoracoscopy: hormone receptor content in pleural metastases due to breast cancer
}

\author{
C. Schwarz*, H. Lübbert ${ }^{\Uparrow}$, W. Rahn\# ${ }^{\#}$ N. Schönfeld*, M. Serke*, R. Loddenkemper*
}

Medical thoracoscopy: hormone receptor content in pleural metastases due to breast cancer. C. Schwarz, H. Lübbert, W. Rahn, N. Schönfeld, M. Serke, R. Loddenkemper. (C) ERS Journals Ltd 2004.

ABSTRACT: Pleural metastases are common in the course of breast cancer, but, to date, the role of oestrogen receptor (OR) and progesterone receptor (PgR) content in metastatic tissue has been poorly evaluated.

A series of 50 consecutive patients with a history of breast cancer (median age $64 \mathrm{yrs}$, range 40-86 yrs), which presented with pleural effusion and therefore underwent medical thoracoscopy, was analysed. Metastatic pleural involvement was histologically confirmed in all patients. The hormone receptor status of the pleural metastases was investigated using the immunohistochemical method in 49 and the biochemical method in 31 cases. The immunohistochemical test was performed using monoclonal antibodies. Biochemical analysis was performed on specimens quick-frozen in liquid nitrogen. $O R$ and PgR were measured with the dextran-coated charcoal assay and Scatchard analysis.

Immunohistochemical analysis yielded 29 OR-positive and $25 \mathrm{PgR}$-positive cases and biochemical analysis yielded 16 OR-positive and four PgR-positive cases, sometimes discrepant to hormone status of the primary breast cancer. Using a semiquantitative immunoreactive score, there was a significant association between receptor positivity and survival, but only for PgR positivity.

Immunohistochemical and biochemical detection of hormone receptors (oestrogen and progesterone) in pleural metastases of breast cancer is feasible based on medical thoracoscopy as the method of choice, by which sufficient specimens may be obtained. The receptor status may enable a decision on antihormonal treatment. Whether a positive receptor status in pleural metastatic tissue is associated with a better prognosis remains to be confirmed.

Eur Respir J 2004; 24: 728-730.
*Dept of Pneumology II, Lungenklinik Heckeshorn/Zentralklinik Emil von Behring,

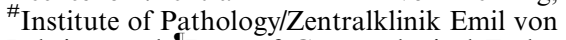
Behring, and "Dept of Gynaecological Endocrinology, Infertility and Family Planning, University Hospital Benjamin Franklin, Joint Facility of Freie Universität Berlin and Humboldt-Universität zu Berlin, Berlin, Germany.

Correspondence: R. Loddenkemper Lungenklinik Heckeshorn

Zum Heckeshorn 33

Berlin

Germany

Fax: 49302618980

E-mail: r.loddheck@zedat.fu-berlin.de

Keywords: Breast cancer malignant pleural effusion medical thoracoscopy oestrogen and progesterone receptors

Received: October 132003

Accepted after revision: January 212004
Breast cancer is the most frequent tumour in females. Pleural metastases are common in the course of breast cancer, affecting $10-50 \%$ of breast cancer patients [1-3]. This pleural involvement may be the first and only manifestation of recurrent disease in $20-40 \%$ of these patients $[1,2,4]$.

The oestrogen and progesterone receptors (OR and $\mathrm{PgR}$ ) of the primary breast tumour are determined as a guide to prognosis $[5,6]$. In metastatic pleural tissue, determination of OR and PgR has been poorly evaluated so far, and the role of hormone receptors is still undefined. No studies exist on a possible correlation of $\mathrm{OR}$ and $\mathrm{PgR}$ in breast cancer primaries and their pleural metastases, and it is not known whether the patients' prognosis is influenced by their OR and PgR status. The answers to these questions may help to decide upon the best therapy.

\section{Material and methods}

In a retrospective study, 50 patients with pleural metastases secondary to breast cancer, who all had undergone medical thoracoscopy either for diagnostic or therapeutic purposes, were investigated in 1991-1996 at Lungenklinik Heckeshorn, Berlin, Germany. The patients' median age was 64 yrs (range
40-86). The median time from the first diagnosis of breast cancer to the development of pleural metastases was $8 \mathrm{yrs}$, with a wide range of $0-28$ yrs.

The diagnosis was confirmed by medical thoracoscopy in all patients. The specimens for hormone receptor determination were obtained during this procedure.

Thoracoscopy was performed according to the technique used at the Lugenklinik Heckeshorn and Institute of pathology/ Zentralklinik Emil von Behring, Berlin, Germany [7], under local anaesthesia with single entry. Biopsies were taken under visual control from macroscopically suspicious areas, mainly from the parietal pleura (chest wall, diaphragm).

The hormone receptor status of the pleural metastases was investigated using the immunohistochemical method in 49 cases and the biochemical method in 31 cases.

The dextran-coated charcoal (DCC) assay method requires specimens weighing 250-500 mg. OR and, subsequently, PgR status was determined.

\section{Immunohistochemical assay}

Tumour tissue was quick-frozen in liquid nitrogen, and monoclonal antibodies (ER-ICA and PgR-ICA; Dako, 
Hamburg, Germany) were used. OR were determined using the clone 1D5 [8], and PgR using the clone PgR 636 [9].

The semiquantitive immunoreactive score (IRS) was applied to identify positive cases for the immunohistochemical method [10]. Based on the percentage of positive tumour cells, five classes were defined (no positive cells, $<10,10-50,51-80,>80 \%$ ), while the mean staining intensity was evaluated separately in three classes (weak, moderate and strong). By multiplying the score values, an IRS scale of 1-12 was obtained.

\section{Biochemical assay (dextran-coated charcoal assay method)}

The minimum weight of cancer tissue for the DCC assay was $250 \mathrm{mg}$. For biochemical detection of the steroid hormone receptors in cytosol, specimens were quick-frozen in liquid nitrogen and measured using DCC assay and Scatchard plots to analyse the types of binding [11]. Values $>20 \mathrm{fmol} \cdot \mathrm{mg}^{-1}$ protein were defined as the cut-off level positive for OR and PgR.

Statistical evaluation of the patients' survival was achieved by the Kaplan-Meier test.

\section{Results}

\section{Primary}

The primary malignant tumour of the breast was localised on the left side in 28 cases, on the right in 19 cases, and on both sides in three cases. Histological evaluation had yielded 43 invasive ductal carcinomas, three noninvasive ductal carcinomas and four invasive lobular carcinomas.

In 32 patients, the OR and $\mathrm{PgR}$ status of the primary tumour was known. The OR status was positive in 17 cases and the PgR status positive in 12 cases. Both OR and PgR were positive in eight cases. The OR status was negative in 15 cases and the PgR status negative in 20 cases.

\section{Metastases}

In all cases, a malignant pleural effusion was present, localised on the left in 23 , on the right in 19 , and on both sides in six patients. In total, 31 cases showed pleural involvement on the same side as the primary breast cancer, but, in 19 cases, the opposite side was involved.

It was possible to examine tissue of the pleural metastases with the immunohistochemical technique in all 49 cases for $\mathrm{OR}$ and PgR. With the DCC technique, which requires more tumour tissue, 30 out of 31 cases for OR and 12 out of 31 cases for PgR could be measured.

Positive OR were found in $59 \%$ (29/49) of cases and $51 \%$ (25/49) of cases for PgR, using the immunohistochemical assay. The DCC assay was positive for OR in 53\% (16/30) of cases and 33\% (4/12) of cases for PgR.

With the immunohistochemical method, the concordance between breast cancer and pleural metastases was $65 \%(20 / 31)$ for OR and 58\% (18/31) for PgR, using the immunohistochemical method in 31 cases and the DCC method in 19 cases. The comparison between primary and secondary cancer using the DCC method found 47\% (9/19) for OR and 86\% (6/7) for PgR.

The reason for the small number of patients with detected PgR (DCC) was that the DCC method requires specimens weighing $250-500 \mathrm{mg}$. The material was already partly consumed for determination of the first receptor (OR) and this residual specimen was not sufficient for the second receptor measurement $(\mathrm{PgR})$.

\section{Survival}

Using the DCC assay, the median survival after thoracoscopy was 2.58 yrs for patients with positive OR and 2.08 yrs for negative OR. The result for positive PgR was 2.58 yrs and $1.17 \mathrm{yrs}$ for negative $\mathrm{PgR}$. These results were not statistically significant.

The survival for immunhistochemically detected OR was 2.08 yrs with positive OR and 2.58 yrs with negative OR. Again, these results were not statistically significant. The median survival was 2.67 yrs for positive PgR and 1.08 yrs for negative PgR. This result showed a high statistical significance $(\mathrm{p}=0.0016)$.

\section{Discussion}

Breast cancer is a frequent disease in females and hormone receptors are routinely determined, but studies on the hormone receptor status of metastatic tissue in the pleura have not yet been implemented. In the only relevant article in the literature, LEVINE et al. [12] describe four cases with pleural metastases secondary to breast cancer and the removal of pleural specimens by medical thoracoscopy for the detection of OR and PgR.

Investigations of $\mathrm{OR}$ and $\mathrm{PgR}$ in metastatic tissue other than pleural have been carried out [13-24]. In these studies, 28-182 breast cancer patients with metastatic disease and detected $\mathrm{OR}$ and $\mathrm{PgR}$ were analysed. Hormone receptor investigation showed widely differing results. A concordance of hormone receptors between primary and secondary cancer was found in $19-91 \%$ of patients. These results show a low rate of concordance and underline the heterogeneity between primary and secondary cancer. KAMBY et al. [22] analysed the concordance of the OR in primary breast cancer and metastatic tissue of the lymph nodes, liver and bone, and found that the concordance was $90 \%$ for lymph node metastases, $75 \%$ for liver metastases and $58 \%$ for bone metastases. These data show a lower concordance between primary and secondary tumour with progressing metastatic disease, possibly indicating that the structure of the tumour tissue changes as the disease advances, and that this also may be reflected by the expression of hormone receptors.

The most important result of the current study is the shift from negative OR and PgR in the primary tumour to positive receptors in pleural metastases. This points to the need for tissue samples for hormone receptor determination in both recurrent and metastatic disease in order to decide on the best potential hormone therapy. Regarding pleural metastases secondary to breast cancer, medical thoracoscopy must be considered as the first choice for obtaining specimens from the pleura for hormone receptor detection, as pleurodesis is another advantage of medical thoracoscopy. Talc poudrage can be performed under visual control into the pleural cavity during medical thoracoscopy, and is, at present, probably the most effective method [25-27].

The comparison of both methods used for OR and PgR analyses clearly shows the advantages of the immunohistochemical assay. The specimen removed by medical thoracoscopy may be considerably smaller than that for the DCC assay ( $>250 \mathrm{mg}$ is needed for the DCC method). PgR could be investigated in only 12 of 31 cases $(29 \%)$ in the current study. In 19 cases $(61 \%)$, the specimen was not sufficient for analysis. Another advantage of the immunohistochemical assay is that the tissue does not have to be frozen in liquid nitrogen. If tissue is not frozen immediately for the DCC method, a loss of receptor content may lead to insufficient results. The use of paraffin-embedded tissue, which can be kept for several years, is a further advantage. Also, the costs for immunohistochemical investigation in the Institute of Pathology, Berlin, Germany, are $33 \%$ below those of the DCC method. 
In the current study, survival after manifestation of pleural metastases in patients was studied in relation to OR and PgR. Only the comparison of cases with positive and negative PgR measured by immunohistochemical assay showed a significantly longer survival for PgR-positive patients, but the other associations between receptors and survival did not reveal a statistical significance. This question was investigated in a study by COLLETT et al. [28], who examined 977 females with breast cancer. The authors could confirm the association between positive PgR status and survival of breast cancer patients. The PgR-positive breast cancer patients had a significantly longer survival in comparison to $\mathrm{PgR}$-negative patients (2.67 versus $1.08 \mathrm{yrs})$.

MERKLE et al. [29] confirmed the importance of PgR after studying 660 breast cancer patients. The first group was PgRnegative $(n=224)$ and without axillary lymph nodes metastasis. The second group was PgR-positive $(n=128)$ and with axillary lymph node metastasis. The 5-yr survival rate was nearly the same, with $73.8 \%$ versus $75.5 \%$. Again, this study again shows the relevance of PgR for patient survival.

Recently, it was demonstrated that overexpression of HER2/ neu in tissue is a good prognostic marker in breast cancer. Overexpression of HER2/neu is associated with a worse prognosis in primary breast cancer [30]. Unfortunately, this method was not yet available for comparison during the period of the current study (1991-1996).

In conclusion, the current authors suggest that hormone receptor status of breast cancer metastases should be determined. For pleural metastases causing pleural effusion, medical thoracoscopy is the method of choice to obtain sufficient specimens. The receptor status allows a decision on hormonal treatment. Whether a positive receptor status in pleural metastatic tissue is associated with a better prognosis remains to be confirmed.

\section{References}

1. Weichselbaum R, Marck A, Hellman S. Pathogenesis of pleural effusion in carcinoma of the breast. Int $J$ Radiat Oncol Biol Phys 1977; 2: 963-965.

2. Kreisman H, Wolkove N, Schwartz Finkelstein H, Cohen C, Margolese R, Frank H. Breast cancer and thoracic metastases: review of 119 patients. Thorax 1983; 38: 175-179.

3. Fracchia AA, Knapper WH, Carey JT, Farrow JH. Intrapleural chemotherapy for effusion from metastatic breast carcinoma. Cancer 1970; 26: 626-629.

4. Fentiman IS, Rubens Rd, Hayward JL. Control of pleural effusions in patients with breast cancer. A randomized trial. Cancer 1981; 52: 737-739.

5. Clark GM, McGuire WL, Hubay CA, Pearson OH, Marshall JS. Progesterone receptors as a prognostic factor in stage II breast cancer. N Engl J Med 1983; 309: 1343-1347.

6. Kamby C, Rose C, Iversen H, Holm NV, Andersen KW, Thorpe SM. Pattern of metastases in human breast carcinoma in relation to estrogen receptor status. Anticancer Res 1986; 6: 107-112.

7. Loddenkemper R. Thoracoscopy: state of the art. Eur Respir $J$ 1998; 11: 213-221.

8. Al Saati T, Clamens S, Cohen-Knafo E, et al. Production of monoclonal antibodies to human estrogen receptor (ER) protein using recombinant ER (RER). Int J Cancer 1993; 55: 651-654.

9. Kraus WL, Montano MM, Katzenellenbogen BS. Cloning of the rat progesterone receptor gene 5'-region and identification of two functionally distinct promoters. $\mathrm{Mol}$ Endocrinol 1993; 7: 1603-1616.

10. Remmle W, Stegner HE. Vorschlag zur einheitlichen Definition eines Immunreaktiven Score (IRS) für den immunhistochemischen Östrogenrezeptor-Nachweis (ER-ICA) im
Mammakarzinomgewebe [Recommendation for uniform definition of an immunoreactive score (IRS) for immunohistochemical estrogen receptor detection (ER-ICA) in breast cancer tissue]. Pathologe 1987; 8: 138-140.

11. Scatchard DG. The attraction of proteins for small molecules and ions. Ann NY Acad Sci 1949; 51: 660-663.

12. Levine MN, Young JEM, Ryan ED, Newhouse MT. Pleural effusion in breast cancer. Thoracoscopy for hormone receptor determination. Cancer 1986; 57: 324-327.

13. Rosen PP, Menendez-Botet CJ, Urban JA, Fracchia A, Schwartz MK. Estrogen receptor protein (ERP) in multiple tumor specimens from individual patients with breast cancer. Cancer 1977; 39: 2194-2200.

14. Webster DJ, Bronn DG, Minton JP. Estrogen receptor levels in multiple biopsies from patients with breast cancer. $\mathrm{Am}$ J Surg 1978; 136: 337-338.

15. Hoehn JL, Plotka ED, Dickson KB. Comparison of estrogen receptor levels and regional metastatic carcinoma of the breast. Ann Surg 1979; 190: 69-71.

16. Brennan MJ, Donegan WL, Appleby DE. The variability of estrogen receptors in metastatic breast cancer. Am J Surg 1979; 137: 260-262.

17. Klinga K, Kaufmann M, Runnebaum B, Kubli F. Distribution of estrogen and progesterone receptors on primary tumor and lymph nodes in individual patients with breast cancer. Oncology 1982; 39: 337-339.

18. Holdaway IM, Bowditch JV. Variation in receptor status between primary and metastatic breast cancer. Cancer 1983; 52: 479-485.

19. Jakesz R, Dittrich C, Hanusch J, et al. Simultaneous and sequential determination of steroid hormone receptors in human breast cancer. Influence of intervening therapy. Ann Surg 1985; 201: 305-310.

20. Alanko A. Variation of estrogen and progesterone receptor status in breast cancer. Ann Clin Res 1985; 17: 10-14.

21. Andersen J, Poulsen HS. Relationship between estrogen receptor status in the primary tumor and its regional and distant metastases. An immunohistochemical study in human breast cancer. Acta Oncol 1988; 27: 761-765.

22. Kamby C, Rasmussen BB, Kristensen B. Oestrogen receptor status of primary breast carcinomas and their metastases. Relation to pattern of spread and survival after recurrence. Br J Cancer 1989; 60: 252-257.

23. Li BD, Byskosh A, Molteni A, Duda RB. Estrogen and progesterone receptor concordance between primary and recurrent breast cancer. J Surg Oncol 1994; 57: 71-77.

24. Kuukasjärvi T, Kononen J, Helin H, Holli K, Isola J. Loss of estrogen receptor in recurrent breast cancer is associated with poor response to endocrine therapy. J Clin Oncol 1996; 14: 2584-2589.

25. Fentiman IS, Rubens RD, Haward JL. A comparison of intracavitary talc and tetracycline for the control of pleural effusions secondary to breast cancer. Eur J Cancer Clin Oncol 1986; 22: 1079.

26. Hamed H, Fentiman IS, Chaudary MA, et al. Comparison of intracavitary bleomycin and talc for control of pleural effusion secondary to carcinoma of the breast. $\mathrm{Br} J$ Surg 1989; 76: 1266

27. American Thoracic Society. Management of malignant pleural effusion. Am J Respir Crit Care Med 2000; 162: 1987-2001.

28. Collett K, Hartveit F, Skjaerven R, Maehle BO. Prognostic role of oestrogen and progesterone receptors in patients with breast cancer: relation to age and lymph node status. $J$ Clin Pathol 1996; 49: 920-925.

29. Merkle E, Seidl I, Bahr I, et al. Long term study of the significance of hormone receptors as prognostic factors in breast cancer. Geburtshilfe Frauenheilkd 1990; 50: 528532.

30. Taucher S, Rudas M, Mader RM, et al. Prognostic markers in breast cancer: the reliability of HER2/neu status in core needle biopsy of 325 patients with primary breast cancer. Wien Klein Wochenschr 2004; 116: 26-31. 